\title{
Priming effect on the physiological potential of maize seeds under abiotic stress ${ }^{1}$
}

\author{
Geraldo Candido Cabral Gouveia ${ }^{2}$, Flávio Ferreira da Silva Binotti ${ }^{3}$, Edilson Costa ${ }^{3}$
}

\section{ABSTRACT}

Abiotic stress directly influences seed performance, so poor-vigor seeds under adverse conditions tend to show lower germination speed and rate. By controlling the hydration level of seeds (i.e., priming) with the addition of chemical agents, it is possible to elicit the maximum physiological potential of seeds, even under stress conditions. This study aimed to evaluate the priming effect of different chemical agents on the physiological potential of maize seeds under abiotic stress (polyethylene glycol induced water stress, hypoxia, low temperature and salt stress after controlled deterioration). The experimental design was completely randomized, in a $5 \times 2$ factorial scheme, consisting of different chemical agents used to hydrate the seeds [control without priming; control primed with water; calcium nitrate $(0.2 \%)$; amino acid L-phenylalanine $(0.05 \%)$; amino acid L-phenylalanine $(0.5 \%)+$ calcium nitrate $(0.2 \%)$ ] and 2 seed lots, with four replicates. Priming with calcium nitrate lead to a greater germination and higher emergence rate of the seedlings under suboptimal temperature conditions, and seeds that underwent controlled deterioration showed greater germination levels with the use of calcium nitrate + phenylalanine in the priming process, regardless of the lot used. In general, seed priming allowed a greater expression of seed vigor, even though an interaction with lots was observed in some variables.

KEYWORDS: Zea mays; controlled deterioration; phenylalanine.

\section{INTRODUCTION}

Brazil is currently the third largest producer of maize in the world, behind the United States and China, with an estimated production of 69 million tons in the 2015/2016 harvest (Conab 2016). For this massive production, the use of high-quality seeds is crucial. High-vigor seeds yield better-performing seedlings, achieving a rapid and uniform emergence (Ghassemi-Golezani \& Dalil 2011).

\section{RESUMO}

Efeito do condicionamento no potencial fisiológico de sementes de milho sob estresse abiótico

O estresse abiótico influencia diretamente no desempenho das sementes, sendo que sementes com baixo vigor, sob condições adversas, tendem a apresentar menor velocidade e percentual de germinação. A hidratação controlada das sementes com agentes químicos pode expressar o máximo potencial fisiológico das mesmas, mesmo quando submetidas a condições de estresse. Objetivou-se avaliar o potencial fisiológico de sementes de milho hidratadas com diferentes agentes químicos e submetidas a estresse abiótico (estresse hídrico induzido por polietileno glicol, hipóxia, baixa temperatura e estresse salino após deterioração controlada). O delineamento experimental utilizado foi o inteiramente casualizado, em esquema fatorial $5 \times 2$, sendo constituído por agentes químicos empregados na hidratação das sementes [testemunha - sem hidratação; controle com água; nitrato de cálcio (0.2\%); aminoácido L-fenilalanina (0.05\%); aminoácido L-fenilalanina $(0.5 \%)+$ nitrato de cálcio $(0.2 \%)$ ] e 2 lotes de sementes, com quatro repetições. A hidratação controlada com nitrato de cálcio propicia maior germinação e emergência de plântulas em condição de temperatura subótima, e sementes oriundas da deterioração controlada apresentam maior germinação com o uso de nitrato de cálcio mais fenilalanina na hidratação das sementes, independentemente do lote utilizado. De modo geral, a hidratação das sementes possibilitou maior expressão de vigor, mesmo que interação com os lotes tenha sido observada em algumas variáveis.

PALAVRAS-CHAVE: Zea mays; deterioração controlada; fenilalanina.

Vigor testing is of paramount importance to verify possible differences in the physiological potential of seed lots and can supplement the data obtained from germination tests (Santos et al. 2003).

There are several ways to analyze seed vigor in maize crops, simulating stress conditions that will expose the seeds to extreme situations, such as water stress induced by polyethylene glycol (Huang \& Song 2013), controlled deterioration (Zucareli et al. 2011), germination at low temperatures ( $\mathrm{Hu}$ et al. 2016),

1. Manuscript received in Apr./2017 and accepted for publication in Sep./2017 (http://dx.doi.org/10.1590/1983-40632016v4746560).

2. Universidade Estadual Paulista "Júlio de Mesquita Filho", Faculdade de Engenharia de Ilha Solteira, Ilha Solteira, SP, Brasil. E-mail: geraldocgouveia@hotmail.com.

3. Universidade Estadual de Mato Grosso do Sul, Cassilândia, MS, Brasil.E-mails: binotti@uems.br, mestrine@uems.br. 
submersion in water (Grzybowski et al. 2015) and saline stress (Agami 2013).

Seed priming may be an alternative for improving seed vigor. Priming may be performed with the use of substances that contribute to the expression of the seed physiological potential (Batista et al. 2016). Seed priming may promote more balanced germination rates and higher germination speed, in addition to faster seedling growth under adverse conditions, for instance, under abiotic stress (Arif et al. 2014). However, few studies have been conducted on seed priming using the amino acid phenylalanine, which is a precursor of phenolic compounds that increase in response to different types of stress, e.g., related to the plant defense systems and adaptation to adverse situations (Stangarlin et al. 2011). According to Batista et al. (2016), priming with $\mathrm{KNO}_{3}$ and $\mathrm{Ca}\left(\mathrm{NO}_{3}\right)_{2}$ enhance physiological seed quality, producing seeds with high tolerance to stress under high temperature.

In view of the above, this study aimed to evaluate the priming effect of different chemical agents on the physiological potential of maize seeds submitted to abiotic stressful conditions (polyethylene glycol - PEG induced water stress, hypoxia, low temperature and salt stress after controlled deterioration).

\section{MATERIAL AND METHODS}

The experiment was carried out in a greenhouse of the Universidade Estadual de Mato Grosso do Sul, in Cassilândia, Mato Grosso do Sul state, Brazil, in 2016.

The maize seeds (Zea mays; 2B512 cultivar) used in this study were supplied by Dow Sementes. The experimental design was completely randomized, with a $5 \times 2$ factorial scheme. Treatments consisted of five chemical agents used to hydrate the seeds [control without priming; control primed with water; calcium nitrate $(0.2 \%)$; amino acid L-phenylalanine $(0.05 \%)$; amino acid L-phenylalanine $(0.5 \%)+$ calcium nitrate $(0.2 \%)]$ and 2 seed lots, with four replicates.
Data on the initial physiological quality of the maize seed lots are shown in Table 1.

For priming, maize seeds were placed between 4 sheets of germitest paper ( 2 sheets under and 2 sheets over the seeds) moistened with different chemical agents at the ratio of 3 times the paper dry mass, for a period of $6 \mathrm{~h}$, kept in a germination chamber at a temperature of $25{ }^{\circ} \mathrm{C}$ (adapted from Ferreira 2011). Then, the seeds were dried in a dry chamber, for hygroscopic equilibrium recovery. After the treatment, the seeds were stored for 5 days and, afterwards, physiological and quality analyses were performed.

The following tests were carried out:

a) Electrical conductivity: conducted with 4 subsamples of 50 seeds per priming treatment (Miguel \& Marcos Filho 2002);

b) First germination count and seed germination: consisted of four subsamples of 50 seeds per treatment, using three germitest paper sheets as substrate, moistened with water at the ratio of 3 times the paper dry mass, germinated at $25{ }^{\circ} \mathrm{C}$, at a 12-h photoperiod (Brasil 2009);

c) Seedling emergence: conducted in a greenhouse, using four subsamples of 50 seeds per treatment, sowed at $1 \mathrm{~cm}$ depth in trays, using sand as substrate. The rate of emerged seedlings was registered until stand uniformity, being considered emerged the seedlings with shoot length not less than $20 \mathrm{~mm}$. The results were expressed as percentage of emerged seedlings;

d) Emergence speed index: conducted in a greenhouse jointly with the seedling emergence test (Maguire 1962);

e) Primary root and shoot length: four subsamples of 20 maize plants with 14 days after emergence were randomly selected from each treatment in the emergence test, and primary root and shoot length were measured in centimeters (Vieira \& Kryzanowski 1999);

f) Shoot and root dry mass: four subsamples of 20 plants with 14 days after emergence were used from each treatment in the emergence test. Dry

Table 1. Initial physiological quality of the maize seed lots.

\begin{tabular}{|c|c|c|c|c|}
\hline \multirow{2}{*}{ Seed lot } & \multicolumn{2}{|c|}{ Germination (\%) } & \multirow{2}{*}{$\begin{array}{l}\text { Germination speed } \\
\text { index }\end{array}$} & \multirow{2}{*}{$\begin{array}{l}\text { Electrical conductivity } \\
\left(\mu \mathrm{S} \mathrm{cm}^{-1} \mathrm{~g}^{-1}\right)\end{array}$} \\
\hline & First count & Total & & \\
\hline Lot 1 & 86 & 94 & 11.32 & 13.15 \\
\hline Lot 2 & 84 & 94 & 11.21 & 15.01 \\
\hline
\end{tabular}


phytomass was determined after drying shoot and root in a forced air circulation oven at an average temperature of $65^{\circ} \mathrm{C}$, for a period of $72 \mathrm{~h}$. Values were expressed as mg seedling ${ }^{-1}$.

In addition to the evaluations of germination and growth with water and normal temperature, the plants were submitted to the following abiotic stresses, before or during some of the tests previously described:

a) Water restriction (during the germination test) - PEG 6000: for the water deficit simulation, a polyethylene glycol solution (PEG 6000) was used at the osmotic potential of $-0.2 \mathrm{MPa}$, equivalent to the concentration of $119.571 \mathrm{~g}$ of deionized PEG L-1 of $\mathrm{H}_{2} \mathrm{O}$ (Moterle et al. 2008). The solution containing PEG 6000 was supplied directly to the germination substrate, and the germination test was performed according to recommendations for maize crops (Brasil 2009);

b) Oxygen restriction (before the germination test): hypoxia was induced by submersion of seeds in water for $24 \mathrm{~h}$ (Grzybowski et al. 2015) and the germination test was conducted according to recommendations for maize crops (Brasil 2009);

c) High relative humidity and temperature: controlled deterioration was performed before germination. Deterioration was simulated according to Padilha et al. (2001), by increasing the water content of the seeds to $20 \%$ moisture, by soaking them in plastic cups (200 seeds per cup) containing $450 \mathrm{~mL}$ of water. Afterwards, the seeds were conditioned in plastic packaging internally coated with aluminum, with 200 seeds per package/ treatment. The packages were heat sealed and kept at $10^{\circ} \mathrm{C}$, for $24 \mathrm{~h}$, in a refrigerator, for standardization of the seed moisture content. Then, each package was conditioned and sealed in resistant plastic bag and kept in a $40{ }^{\circ} \mathrm{C}$ water bath, for $48 \mathrm{~h}$. After deterioration, the germination test was carried out following recommendations for maize crops (Brasil 2009);

d) Germination at low temperatures: it was performed similarly to the germination test, but kept in a germination chamber at $18{ }^{\circ} \mathrm{C}$ (adapted from Vieira \& Kryzanowski 1999). The evaluations were performed at 4 days (first count) and at 7 days (germination test) (Brasil 2009);

e) Saline stress - emergence in saline substrate: the saline environment simulation was carried out in trays containing sand and, before sowing the seeds, the substrate was moistened up to $60 \%$ of field capacity with a $\mathrm{NaCl}$ solution, to simulate a saline soil. Two liters of solution were used per tray, with a concentration of $0.7 \%$ of $\mathrm{NaCl}$ (adapted from Silva et al. 2016). Subsequently, the seeds were sown and the emergence test and emergence speed index were performed.

All data were analyzed by analysis of variance, using the F-test. When the F value was at a $5 \%$, the Scott-Knott test was used to compare the means for the chemical agents.

\section{RESULTS AND DISCUSSION}

Figure 1 displays the data on the moisture content of the maize seeds before and after the priming process.

The priming process followed the same standard for lots 1 and 2, and the seeds primed with chemical agents showed a lower moisture content than the seeds primed with water alone. The different chemical agents decreased the osmotic potential of the seeds, leading to a lower water absorption.

For the first germination count and the seed germination test without abiotic stress simulation (Table 2) and with oxygen restriction (submersion in water) (Table 3), the factors under analysis showed isolated influence, with no significant interactions observed between them.

The different chemical agents used in the seed priming did not influence the germination test

Table 2. First germination count (4 days) and total germination (7 days) of maize seeds primed with different chemical agents.

\begin{tabular}{lcc}
\hline \multirow{2}{*}{ Treatment } & \begin{tabular}{c} 
Germination without abiotic stress (\%) \\
\cline { 2 - 3 } Seed lots \\
count
\end{tabular} & $\begin{array}{c}\text { Germination } \\
\text { test }\end{array}$ \\
Lot 1 & $85 \mathrm{~A} *$ \\
Lot 2 & $85 \mathrm{~A}$ & $94 \mathrm{~A}$ \\
Seed priming & $94 \mathrm{~A}$ \\
Control & $80 \mathrm{~B}$ & $92 \mathrm{~A}$ \\
Water & $85 \mathrm{~A}$ & $94 \mathrm{~A}$ \\
Phenylalanine (P) & $86 \mathrm{~A}$ & $94 \mathrm{~A}$ \\
Calcium nitrate (CN) & $88 \mathrm{~A}$ & $97 \mathrm{~A}$ \\
CN + P & $88 \mathrm{~A}$ & $94 \mathrm{~A}$ \\
\hline CV (\%) & 3.52 & 3.13 \\
\hline Means followed by different uppercase letters within a column differ from each \\
other by the F-test for the seed lot factor and by the Scott-Knott test for the \\
hydration treatment factor, both at 5\%.
\end{tabular}


(Table 2), possibly due to the fact that the test was carried out under adequate germination conditions. However, priming promoted an increase in the first germination count, when compared to the control.

It is believed that primed seeds achieve the best performance because of repair mechanisms, restructuring of the membrane system and efficient reserve mobilization (Fialho et al. 2010). Regarding the lots used, they were not significantly different, with respect to the germination potential (Table 2).

Table 3. First germination count (4 days) and germination test (7 days) after submersion in water, for lots and priming of maize seeds.

\begin{tabular}{|c|c|c|}
\hline \multirow[b]{2}{*}{ Treatment } & \multicolumn{2}{|c|}{ Germination after submersion in water $(\%)$} \\
\hline & $\begin{array}{l}\text { First germination } \\
\text { count }\end{array}$ & $\begin{array}{l}\text { Germination } \\
\text { test }\end{array}$ \\
\hline \multicolumn{3}{|l|}{ Seed lots } \\
\hline Lot 1 & $44 \mathrm{~A}^{*}$ & $51 \mathrm{~A}$ \\
\hline Lot 2 & $38 \mathrm{~B}$ & $46 \mathrm{~B}$ \\
\hline \multicolumn{3}{|l|}{ Seed priming } \\
\hline Control & $42 \mathrm{~A}$ & $52 \mathrm{~A}$ \\
\hline Water & $42 \mathrm{~A}$ & $48 \mathrm{~A}$ \\
\hline Phenylalanine $(\mathrm{P})$ & $37 \mathrm{~A}$ & $45 \mathrm{~A}$ \\
\hline Calcium Nitrate $(\mathrm{CN})$ & $41 \mathrm{~A}$ & $49 \mathrm{~A}$ \\
\hline $\mathrm{CN}+\mathrm{P}$ & $44 \mathrm{~A}$ & $50 \mathrm{~A}$ \\
\hline $\mathrm{CV}(\%)$ & 14.98 & 12.34 \\
\hline
\end{tabular}

The analysis of the first germination count and the germination test after submersion in water showed that priming did not adversely influence the physiological potential of the seeds (Table 3 ).

Under normal hydration conditions, seeds reach a certain moisture content, allowing the entry of oxygen, which, when dissolved in water, diffuses through the tissues, allowing aerobic respiration. However, submersion in water limits the free diffusion of oxygen and may cause germination to cease (Ogawa et al. 2016). This fact may have contributed to the low germination rates observed, since the growth of the embryonic axis takes place at a high respiratory rate, in order to guarantee both free energy and carbon skeletons to activate the germination process.

An interaction between the factors under analysis was observed for the first germination count tests of seeds under water stress (PEG), seeds at low temperature and seeds submitted to controlled deterioration (Table 4).

The results of the first germination count under water stress showed a high germination rate for the seeds primed with phenylalanine in lot 1 (61\%). Priming with calcium nitrate or phenylalanine also promoted high germination rates in lot 2, with $38 \%$ and $44 \%$, respectively (Table 4 ).

The seeds primed with calcium nitrate achieved higher rates for the first germination count

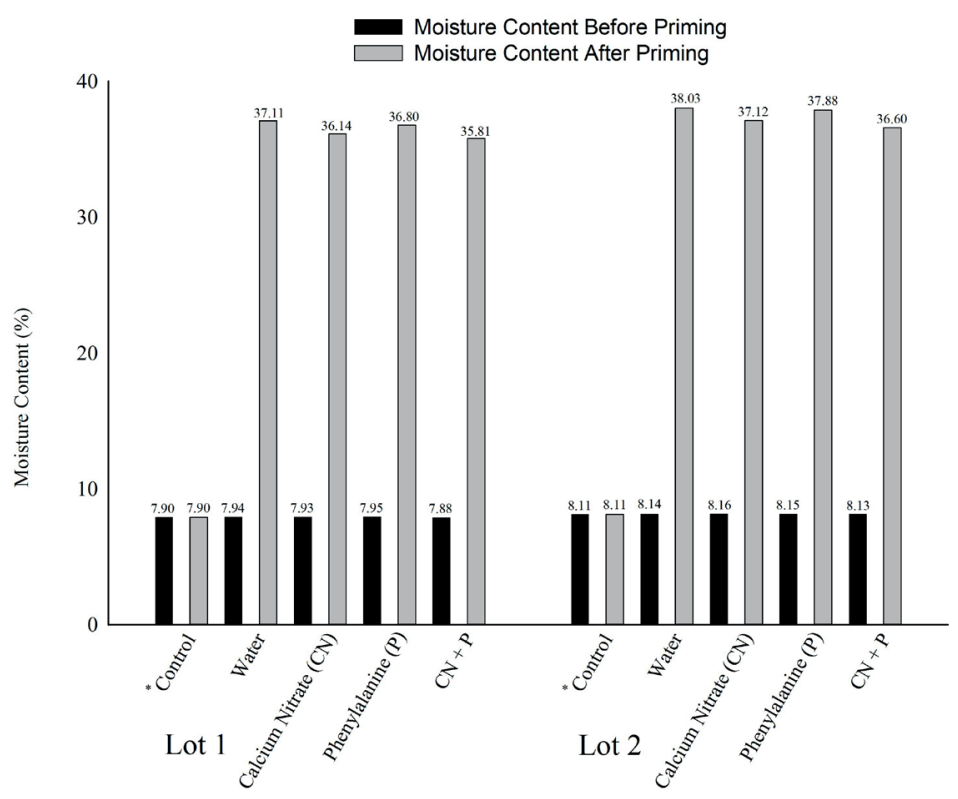

Figure 1. Moisture content before and after the priming of maize seeds. * Control was not primed, therefore, its moisture content remained the same. 
at low temperature in lots 1 and 2 (Table 4). In the first germination count of the seeds after controlled deterioration, the calcium nitrate + phenylalanine treatment resulted in greater germination rates in lot $1(85 \%)$. However, in lot 2, the highest rates for first germination count were observed for the treatments with phenylalanine $(51 \%)$ or calcium nitrate $(44 \%)$ or phenylalanine + calcium nitrate $(57 \%)$.

Phenylalanine is a precursor of phenolic compounds directly involved in plant resistance and defense. It also favors plant adaptation to adverse conditions (Pereira et al. 2009).

Seeds with the highest rates of normal seedlings in the first germination count are considered the most vigorous ones (Nakagawa 1999).

An interaction between the factors under analysis was observed for the germination test at low temperature, then controlled deterioration and electrical conductivity (Table 5).

Seed priming with calcium nitrate provided an increase in the germination rate $(80 \%)$ in lot 1 , for the germination test at low temperature

Table 4. First germination count of seeds under water stress, at low temperature and after controlled deterioration (DET), for lots and priming of maize seeds.

\begin{tabular}{|c|c|c|}
\hline Treatment & Lot 1 & Lot 2 \\
\hline Seed priming & \multicolumn{2}{|c|}{$\begin{array}{c}\text { First count of seeds under water } \\
\text { stress }(\%)\end{array}$} \\
\hline Control & $28 \mathrm{aC}^{*}$ & $29 \mathrm{aB}$ \\
\hline Water & $34 \mathrm{aC}$ & $33 \mathrm{aB}$ \\
\hline Phenylalanine (P) & $61 \mathrm{aA}$ & $38 \mathrm{bA}$ \\
\hline Calcium Nitrate (CN) & $52 \mathrm{aB}$ & $44 \mathrm{aA}$ \\
\hline $\mathrm{CN}+\mathrm{P}$ & $46 \mathrm{aB}$ & $33 \mathrm{bB}$ \\
\hline CV $(\%)$ & \multicolumn{2}{|c|}{14.38} \\
\hline Seed Priming & \multicolumn{2}{|c|}{$\begin{array}{l}\text { First count of seeds at low } \\
\text { temperature }(\%)\end{array}$} \\
\hline Control & $55 \mathrm{aC}$ & $36 \mathrm{bD}$ \\
\hline Water & $62 \mathrm{aB}$ & $48 \mathrm{bC}$ \\
\hline Phenylalanine (P) & $63 \mathrm{aB}$ & $57 \mathrm{aB}$ \\
\hline Calcium Nitrate $(\mathrm{CN})$ & $69 \mathrm{aA}$ & $66 \mathrm{aA}$ \\
\hline $\mathrm{CN}+\mathrm{P}$ & $63 \mathrm{aB}$ & $60 \mathrm{aB}$ \\
\hline CV $(\%)$ & 7.41 & \\
\hline Seed Priming & \multicolumn{2}{|c|}{$\begin{array}{c}\text { First germination count of seeds } \\
\text { after DET }(\%)\end{array}$} \\
\hline Control & $37 \mathrm{aD}$ & $24 \mathrm{bB}$ \\
\hline Water & $71 \mathrm{aB}$ & $25 \mathrm{bB}$ \\
\hline Phenylalanine (P) & $60 \mathrm{aC}$ & $51 \mathrm{aA}$ \\
\hline Calcium Nitrate $(\mathrm{CN})$ & $56 \mathrm{aC}$ & $44 \mathrm{bA}$ \\
\hline $\mathrm{CN}+\mathrm{P}$ & $85 \mathrm{aA}$ & $57 \mathrm{bA}$ \\
\hline CV (\%) & \multicolumn{2}{|c|}{13.57} \\
\hline
\end{tabular}

(Table 5), whereas the control thereof obtained $72 \%$ of germinated seeds. For the same variable in lot 2, the different chemical agents used promoted increased germination rates, but were not different among themselves. In general, seed priming showed higher germination rates in lot 1 , in comparison to lot 2 .

For the germination test of the seeds submitted to controlled deterioration, the treatment with calcium nitrate + phenylalanine showed greater germination rates $(88 \%)$ in lot 1 (Table 5). However, in lot 2, the treatment with calcium nitrate + phenylalanine or phenylalanine alone likewise promoted increased germination rates (61\% and $62 \%$, respectively).

Seed priming promoted higher germination rates in lot 1 than in lot 2, possibly because the seeds in lot 1 showed a higher physiological quality and, therefore, expressed their maximum vigor.

Controlled deterioration testing takes place by subjecting the seed to high humidity and temperature for a long period. Under such conditions, the seeds with low vigor tend to present loss of membrane

Table 5. Germination test at low temperature, germination test after controlled deterioration (DET) and electrical conductivity test, for lots and priming of maize seeds.

\begin{tabular}{|c|c|c|}
\hline Treatment & Lot 1 & Lot 2 \\
\hline Seed priming & \multicolumn{2}{|c|}{$\begin{array}{l}\text { Germination test at low } \\
\text { temperature }(\%)\end{array}$} \\
\hline Control & $72 \mathrm{aD}^{*}$ & $69 \mathrm{bC}$ \\
\hline Water & $74 \mathrm{aC}$ & $71 \mathrm{bB}$ \\
\hline Phenylalanine (P) & $77 \mathrm{aB}$ & $74 \mathrm{bA}$ \\
\hline Calcium Nitrate $(\mathrm{CN})$ & $80 \mathrm{aA}$ & $76 \mathrm{bA}$ \\
\hline $\mathrm{CN}+\mathrm{P}$ & $74 \mathrm{aC}$ & $73 \mathrm{aA}$ \\
\hline CV (\%) & \multicolumn{2}{|c|}{6.24} \\
\hline Seed priming & \multicolumn{2}{|c|}{$\begin{array}{c}\text { Germination test after } \\
\text { DET }(\%)\end{array}$} \\
\hline Control & $41 \mathrm{aD}$ & $27 \mathrm{bC}$ \\
\hline Water & $76 \mathrm{aB}$ & $36 \mathrm{bC}$ \\
\hline Phenylalanine (P) & $63 \mathrm{aC}$ & $62 \mathrm{aA}$ \\
\hline Calcium Nitrate $(\mathrm{CN})$ & $61 \mathrm{aC}$ & $48 \mathrm{bB}$ \\
\hline $\mathrm{CN}+\mathrm{P}$ & $88 \mathrm{aA}$ & $61 \mathrm{bA}$ \\
\hline $\mathrm{CV}(\%)$ & \multicolumn{2}{|c|}{12.82} \\
\hline Seed priming & \multicolumn{2}{|c|}{$\begin{array}{l}\text { Electrical conductivity test } \\
\qquad\left(\mu \mathrm{S} \mathrm{cm}^{-1} \mathrm{~g}^{-1}\right)\end{array}$} \\
\hline Control & $11.71 \mathrm{bA}$ & $15.54 \mathrm{aA}$ \\
\hline Water & $10.53 \mathrm{bB}$ & $12.79 \mathrm{aB}$ \\
\hline Phenylalanine (P) & $8.48 \mathrm{bC}$ & $9.41 \mathrm{aE}$ \\
\hline Calcium Nitrate $(\mathrm{CN})$ & $8.49 \mathrm{bC}$ & $9.96 \mathrm{aD}$ \\
\hline $\mathrm{CN}+\mathrm{P}$ & $10.18 \mathrm{aB}$ & $10.43 \mathrm{aC}$ \\
\hline CV (\%) & \multicolumn{2}{|c|}{2.74} \\
\hline
\end{tabular}


integrity. Consequently, the free radicals produced due to lipid peroxidation in the deterioration process react with the lipids of the cell membranes, damaging their structure and releasing seed reserves (Padilha et al. 2001), a fact that may have contributed to the lower germination rates in lot 2 .

The seeds primed with phenylalanine or calcium nitrate in lot 1 and phenylalanine in lot 2 obtained the lowest electrical conductivity readings, indicating lower cell damage. However, seeds from lot 1 had even lower readings, if compared to lot 2 (Table 5). In general, the lowest conductivity readings were observed for the primed seeds. Similar results were obtained by Oliveira \& Gomes-Filho (2010), in sorghum seeds moistened with PEG 6000.

Therefore, priming with phenylalanine or calcium nitrate may have provided the seeds with a greater capacity to reorganize the cell membranes, promoting less loss of cell constituents, greater capacity to repair the damages caused to the seed and rapid restructuring of the membranes, thus providing lower conductivities, when compared to the unprimed seeds.

For the emergence tests and emergence speed index with and without saline stress, the factors under analysis had an isolated influence, with no significant interactions between them (Table 6).

Seed priming with phenylalanine or calcium nitrate showed higher emergence rates and emergence speed indices for the seeds that were not submitted to saline stress (Table 6). For seeds submitted to saline

Table 6. Seedling emergence and emergence speed index (ESI) of maize seeds with and without saline stress, for lots and priming.

\begin{tabular}{|c|c|c|c|c|}
\hline \multirow{3}{*}{ Treatment } & \multicolumn{2}{|c|}{ Without saline stress } & \multicolumn{2}{|c|}{ With saline stress } \\
\hline & \multicolumn{4}{|c|}{ 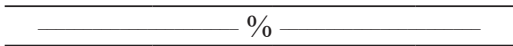 } \\
\hline & Emergence & ESI & Emergence & ESI \\
\hline \multicolumn{5}{|l|}{ Seed lots } \\
\hline Lot 1 & $87 \mathrm{~A}^{*}$ & $6.01 \mathrm{~A}$ & $77 \mathrm{~A}$ & $5.27 \mathrm{~A}$ \\
\hline Lot 2 & $86 \mathrm{~A}$ & $5.97 \mathrm{~A}$ & $69 \mathrm{~B}$ & $4.85 \mathrm{~A}$ \\
\hline \multicolumn{5}{|l|}{ Seed priming } \\
\hline Control & $85 \mathrm{~B}$ & $5.74 \mathrm{~B}$ & $75 \mathrm{~A}$ & $5.22 \mathrm{~A}$ \\
\hline Water & $84 \mathrm{~B}$ & $5.92 \mathrm{~B}$ & $75 \mathrm{~A}$ & $5.28 \mathrm{~A}$ \\
\hline Phenylalanine (P) & $90 \mathrm{~A}$ & $6.16 \mathrm{~A}$ & $67 \mathrm{~A}$ & $4.69 \mathrm{~A}$ \\
\hline Calcium Nitrate (CN) & $89 \mathrm{~A}$ & $6.23 \mathrm{~A}$ & $69 \mathrm{~A}$ & $4.61 \mathrm{~A}$ \\
\hline $\mathrm{CN}+\mathrm{P}$ & $84 \mathrm{~B}$ & $5.90 \mathrm{~B}$ & $79 \mathrm{~A}$ & $5.52 \mathrm{~A}$ \\
\hline $\mathrm{CV}(\%)$ & 4.29 & 4.97 & 15.13 & 16.63 \\
\hline
\end{tabular}

stress, lot 1 had higher emergence rates than lot 2 (respectively $77 \%$ and $69 \%$ ). For the emergency speed index variable with saline stress, the priming and lot factors did not present a significant difference. Emergence under saline stress presented nonsignificant results for the seed priming factor.

Saline stress causes a change in the osmotic potential of the seeds, making water absorption by seeds difficult. Thus, the seed priming before saline stress may have had its beneficial effect annulled, leading to lower germination rates. Similar results were found by Moterle et al. (2006), showing a drop in the germination rate of popcorn maize seeds after addition of salt to the substrate. There was a significant interaction of lots $\mathrm{x}$ priming solutions, regarding shoot length, root length, shoot dry mass and root dry mass (Table 7).

The seeds in lot 1 primed with calcium nitrate or calcium nitrate + phenylalanine yielded plants

Table 7. Shoot length, root length, shoot dry mass and root dry mass, for lots and priming of maize seeds.

\begin{tabular}{|c|c|c|}
\hline Treatment & Lot 1 & Lot 2 \\
\hline Seed priming & \multicolumn{2}{|c|}{ Shoot length $(\mathrm{cm})$} \\
\hline Control & $14.14 \mathrm{aB}^{*}$ & $14.55 \mathrm{aB}$ \\
\hline Water & $13.02 \mathrm{aB}$ & $14.96 \mathrm{aB}$ \\
\hline Phenylalanine (P) & $14.91 \mathrm{aB}$ & $15.04 \mathrm{aB}$ \\
\hline Calcium Nitrate $(\mathrm{CN})$ & $23.06 \mathrm{aA}$ & $20.07 \mathrm{bA}$ \\
\hline $\mathrm{CN}+\mathrm{P}$ & $19.96 \mathrm{aA}$ & $14.20 \mathrm{bB}$ \\
\hline CV $(\%)$ & \multicolumn{2}{|c|}{14.59} \\
\hline Seed priming & \multicolumn{2}{|c|}{ Root length $(\mathrm{cm})$} \\
\hline Control & $21.79 \mathrm{aC}$ & $22.43 \mathrm{aB}$ \\
\hline Water & $24.20 \mathrm{aB}$ & $21.15 \mathrm{aB}$ \\
\hline Phenylalanine $(\mathrm{P})$ & $22.75 \mathrm{aC}$ & $21.65 \mathrm{aB}$ \\
\hline Calcium Nitrate $(\mathrm{CN})$ & $28.30 \mathrm{aA}$ & $24.32 \mathrm{bA}$ \\
\hline $\mathrm{CN}+\mathrm{P}$ & $25.30 \mathrm{aB}$ & $20.61 \mathrm{bB}$ \\
\hline CV $(\%)$ & \multicolumn{2}{|c|}{7.01} \\
\hline Seed priming & \multicolumn{2}{|c|}{ Shoot dry mass (mg seedling ${ }^{-1}$ ) } \\
\hline Control & $58.00 \mathrm{aB}$ & $64.08 \mathrm{aB}$ \\
\hline Water & $62.85 \mathrm{aA}$ & $62.26 \mathrm{aB}$ \\
\hline Phenylalanine $(\mathrm{P})$ & $76.83 \mathrm{aA}$ & $67.08 \mathrm{bB}$ \\
\hline Calcium Nitrate $(\mathrm{CN})$ & $85.30 \mathrm{aA}$ & $74.89 \mathrm{bA}$ \\
\hline $\mathrm{CN}+\mathrm{P}$ & $80.07 \mathrm{aA}$ & $73.63 \mathrm{bA}$ \\
\hline CV $(\%)$ & \multicolumn{2}{|c|}{8.62} \\
\hline Seed priming & \multicolumn{2}{|c|}{ Root dry mass (mg seedling ${ }^{-1}$ ) } \\
\hline Control & $201.18 \mathrm{aB}$ & $203.45 \mathrm{aA}$ \\
\hline Water & $186.50 \mathrm{bB}$ & $211.43 \mathrm{aA}$ \\
\hline Phenylalanine $(\mathrm{P})$ & $205.10 \mathrm{aB}$ & $214.30 \mathrm{aA}$ \\
\hline Calcium Nitrate (CN) & $257.49 \mathrm{aA}$ & $232.05 \mathrm{bA}$ \\
\hline $\mathrm{CN}+\mathrm{P}$ & $240.64 \mathrm{aA}$ & $221.15 \mathrm{aA}$ \\
\hline $\mathrm{CV}(\%)$ & \multicolumn{2}{|c|}{7.09} \\
\hline
\end{tabular}


with larger shoot and root length than the control did. The seeds in lot 2 primed with calcium nitrate yielded plants with shoot length close to $20.07 \mathrm{~cm}$ and root length of $24.32 \mathrm{~cm}$, both higher than those for the control (Table 7).

Higher values for root dry mass were verified for the seeds in lot 1 primed with calcium nitrate or calcium nitrate + phenylalanine, with $257.49 \mathrm{mg}$ and $240.64 \mathrm{mg}$, respectively. These values are higher than the root dry mass observed for the control, which was $201.18 \mathrm{mg}$. Therefore, the primed seeds in lot 1 yielded plants with higher shoot dry mass. It is important to note that calcium nitrate is the only fertilizer among the priming chemical agents. This may explain the higher shoot and root length observed in treatments with calcium nitrate.

In summary, the seeds primed with calcium nitrate led to an increase in plant length and in shoot and root dry masses, possibly due to the beneficial effect of seed hydration on the activation of metabolism (faster germination) and higher availability of nitrogen provided by the nutrients associated with the priming process. As observed by Batista et al. (2015), high-vigor seeds primed with $\mathrm{KNO}_{3}$ and $\mathrm{Ca}\left(\mathrm{NO}_{3}\right)_{2}$ favor plant height and produce C. frutescens seedlings with higher dry mass than the control.

\section{CONCLUSIONS}

1. Priming with calcium nitrate leads to greater germination rates under suboptimal temperature conditions, in addition to better seedling emergence, regardless of the seed lot used;

2. Seeds undergoing controlled deterioration have higher germination rates with the use of calcium nitrate plus phenylalanine in seed priming, regardless of the seed lot used;

3. In general, seed priming allows a greater expression of seed vigor, even though an interaction with seed lots have been observed in some variables.

\section{ACKNOWLEDGMENTS}

To the Coordenação de Aperfeiçoamento de Pessoal de Nível Superior (Capes), for granting the first author a scholarship. This study was funded by the Fundação de Apoio ao Desenvolvimento do Ensino, Ciência e Tecnologia do Estado de Mato Grosso do Sul (FUNDECT - UNIVERSAL MS, Process $N^{\circ} .: 23 / 200.480 / 2014$ ).

\section{REFERENCES}

AGAMI, R. A. Alleviating the adverse effects of $\mathrm{NaCl}$ stress in maize seedlings by pretreating seeds with salicylic acid and 24-epibrassinolide. South African Journal of Botany, v. 88, n. 1, p. 171-177, 2013.

ARIF, M. et al. Evaluating the impact of osmopriming varying with polyethylene glycol concentrations and durations on soybean. International Journal of Agriculture and Biology, v. 16, n. 2, p. 359-364, 2014.

BATISTA, T. B. et al. Aspectos fisiológicos e qualidade de mudas da pimenteira em resposta ao vigor e condicionamento das sementes. Bragantia, v. 74, n. 4, p. 367-373, 2015.

BATISTA, T. B. et al. Priming and stress under high humidity and temperature on the physiological quality of Brachiaria brizantha cv. MG-5 seeds. Acta Scientiarum, v. 38, n. 1, p. 123-127, 2016.

BRASIL. Ministério da Agricultura, Pecuária e Abastecimento. Secretaria de Defesa Agropecuária. Regras para análise de sementes. Brasília, DF: MAPA/ ACS, 2009.

COMPANHIA NACIONAL DE ABASTECIMENTO (Conab). Levantamento da produção de grãos: safra 2015/16. 2016. Available at: <http://www.conab.gov. br/OlalaCMS/uploads/arquivos/16_01_12_09_00_46_ boletim_graos_janeiro_2016.pdf $>$. Access on: Mar. 08, 2017.

FERREIRA, A. C. Condicionamento fisiológico em sementes de milho-doce. 2011.53 f. Dissertação (Mestrado em Agronomia) - Universidade Estadual Paulista, Faculdade de Ciências Agrárias e Veterinárias, Jaboticabal, 2011.

FIALHO, G. S. et al. Osmocondicionamento em sementes de pimenta 'amarela comprida' (Capsicum annuиm L.) submetidas à deterioração controlada. Ciência e Agrotecnologia, v. 34, n. 3, p. 646-652, 2010.

GHASSEMI-GOLEZANI, K.; DALIL, B. Seed ageing and field performance of maize under water stress. African Journal of Biotechnology, v. 10, n. 80, p. 18377-18380, 2011.

GRZYBOWSKI, C. R. S.; VIEIRA, R. D.; PANOBIANCO, $M$. Stress testing in the evaluation of vigour in maize seed. Revista Ciência Agronômica, v. 46, n. 3, p. 590-596, 2015.

HU, S. et al. QTL mapping of low-temperature germination ability in the maize Ibm Syn4 Ril population. PLoS, v. 11, n. 3, p. 1-11, 2016.

HUANG, H.; SONG, S. Change in desiccation tolerance of maize embryos during development and germination at different water potential PEG-6000 in relation to oxidative 
process. Plant Physiology and Biochemistry, v. 68, n. 1, p. 61-70, 2013.

MAGUIRE, J. D. Speed of germination aid in selection and evaluation for seedling and vigour. Crop Science, v. 2, n. 2, p. 176-177, 1962.

MIGUEL, M. V. C.; MARCOS FILHO, J. Potassium leakage and maize seed physiological potential. Scientia Agricola, v. 59, n. 2, p. 315-319, 2002.

MOTERLE, L. M. et al. Germinação de sementes e crescimento de plântulas de cultivares de milho-pipoca submetidas ao estresse hídrico e salino. Revista Brasileira de Sementes, v. 28, n. 3, p. 169-176, 2006.

MOTERLE, L. M. et al. Influência do estresse hídrico sobre o desempenho fisiológico de sementes de híbridos simples de milho-pipoca. Ciência e Agrotecnologia, v. 32, n. 6, p. 1810-1817, 2008.

NAKAGAWA, J. Testes de vigor baseados no desempenho de plântulas. In: KRZYZANOWSKY, F. C.; VIEIRA. R. D.; FRANÇA NETO, J. B. Vigor de sementes: conceitos e testes. Londrina: Abrates, 1999. p. 1-24.

OGAWA, N. S. et al. Submersão de sementes de feijão do grupo preto e desenvolvimento inicial de plântulas. Nucleus, v. 13, n. 2, p. 283-290, 2016.

OLIVEIRA, A. B.; GOMES-FILHO, E. Efeito do condicionamento osmótico na germinação e vigor de sementes de sorgo com diferentes qualidades fisiológicas. Revista Brasileira de Sementes, v. 32, n. 3, p. 25-34, 2010.
PADILHA, L. et al. Relação entre o teste de deterioração controlada e o desempenho de sementes de milho em diferentes condições de estresse. Revista Brasileira de Sementes, v. 23, n. 1, p. 198-204, 2001.

PEREIRA, S. C. et al. Efeito da aplicação foliar de silício na resistência à ferrugem e na potencialização da atividade de enzimas de defesa em cafeeiro. Tropical Plant Pathology, v. 34, n. 4, p. 223-230, 2009.

SANTOS, C. M. R.; MENEZES, N. L.; VILLELA, F. A. Teste de deterioração controlada para avaliação do vigor de sementes de feijão. Revista Brasileira de Sementes, v. 25 , n. 2 , p. 28-35, 2003.

SILVA, R. C.; GRZYBOWSKI, C. R. S.; PANOBIANCO, M. Vigor de sementes de milho: influência no desenvolvimento de plântulas em condições de estresse salino. Revista Ciência Agronômica, v. 47, n. 3, p. 491499, 2016.

STANGARLIN, J. R. et al. A defesa vegetal contra fitopatógenos. Scientia Agraria Paranaenis, v. 10, n. 1, p. 18-46, 2011.

VIERA, R. D.; KRYZANOWSKI, F. C. Teste de condutividade elétrica. In: KRYZANOWSKI, F. C. et al. (Eds.). Vigor de sementes: conceitos e testes. Londrina: Abrates, 1999. p. 4.1-4.26.

ZUCARELI, C. et al. Teste de deterioração controlada na avaliação do vigor de sementes de milho. Revista Brasileira de Sementes, v. 33, n. 4, p. 732-742, 2011. 